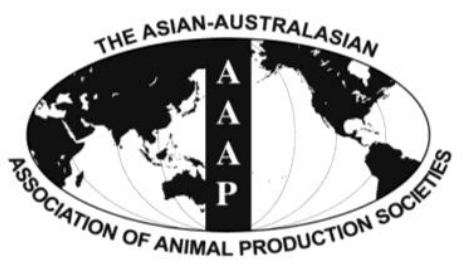

Asian Australas. J. Anim. Sci.

Vol. 26, No. 11 : 1609-1613 November 2013

http://dx.doi.org/10.5713/ajas.2013.13517

www.ajas.info

pISSN 1011-2367 elSSN 1976-5517

\title{
Standardized Total Tract Digestibility of Phosphorus in Copra Expellers, Palm Kernel Expellers, and Cassava Root Fed to Growing Pigs
}

\author{
A. R. Son, S. Y. Shin, and B. G. Kim* \\ Department of Animal Science and Technology, Konkuk University, Seoul 143-701, Korea
}

\begin{abstract}
An experiment was conducted to determine the apparent total tract digestibility (ATTD) and standardized total tract digestibility (STTD) of phosphorus (P) in copra expellers (CE), palm kernel expellers (PKE), and cassava root (CR). Eight barrows (initial $\mathrm{BW}$ of $40.0 \mathrm{~kg}, \mathrm{SD}=4.5$ ) were individually housed in metabolism crates. A replicated $4 \times 3$ incomplete Latin square design was employed involving 4 dietary treatments, 3 periods, and 8 animals. Three experimental diets contained $40 \%$ CE, PKE or CR as the only source of P. A P-free diet mainly based on corn starch, sucrose, and gelatin was also prepared to estimate the basal endogenous loss of P. The marker-to-marker method was used for fecal collection. Values for the ATTD of P in the CE and PKE were greater than in the CR (46.0 and 39.7 vs $-14.0 \%$; $\mathrm{p}<0.05$ ). However, the STTD of P did not differ greatly among the test ingredients $(56.5,49.0$, and $43.2 \%$ in the CE, PKE, and CR, respectively). In conclusion, the ATTD of P values in CE and PKE were greater than that in CR, but the STTD of P did not differ greatly among CE, PKE, and CR. (Key Words: Basal Endogenous Loss of Phosphorus, Feed Ingredient Evaluation, Phosphorus Availability, Standardized Total Tract Digestibility, Swine)
\end{abstract}

\section{INTRODUCTION}

Phosphorus $(\mathrm{P})$ is a material that, with calcium $(\mathrm{Ca})$, mainly composes the bone. To maintain a normal skeleton, animals must be supplied with P. Phosphorus also exists in cell membranes throughout the body in a phospholipid form, and is involved in energy metabolism (Crenshaw, 2001). For these reasons, a sufficient supply of $\mathrm{P}$ is essential.

The digestibility of $\mathrm{P}$ is generally expressed as the apparent total tract digestibility (ATTD) and standardized total tract digestibility (STTD) values (Almeida and Stein, 2010; Kim et al., 2012). The ATTD of P is calculated based on the $\mathrm{P}$ content in the diet and feces. Because the $\mathrm{P}$ in the feces includes $\mathrm{P}$ originating from the body as well as $\mathrm{P}$ derived from the diet, the ATTD of P is less than the real $\mathrm{P}$ digestibility. The major issue in the use of ATTD of P is that the values may not be always additive in mixed diets (NRC, 2012). The STTD of $P$ takes into account the basal endogenous loss (BEL) of $\mathrm{P}$ originating from the body (Almeida and Stein, 2010, 2011; Kim et al., 2012). In a recently released publication of NRC (2012), P requirement and available $\mathrm{P}$ content in the ingredients are presented as

\footnotetext{
* Corresponding Author: B. G. Kim. Tel: +82-2-2049-6255, Fax: +82-2-446-6255, E-mail: bgkim@konkuk.ac.kr Submitted Aug. 19, 2013; Accepted Sept. 30, 2013; Revised Oct. 8, 2013
}

STTD-based $\mathrm{P}$ which are assumed to be additive in mixed diets.

The prices of conventional feed ingredients such as corn and soybean meal have sharply increased in recent years, and thus, efforts to identify alternative feed ingredients have become very important. Because copra expellers (CE), palm kernel expellers (PKE), and cassava root with hulls (CR) are relatively cheap and good sources of nutrients, the increased use of these ingredients is expected (Kim et al., 2001; Son et al., 2012). The CE and PKE were produced by crew-press extraction of oils from coconuts and palm kernels, respectively. The NRC (2012) has reported the values for the STTD of P in CE, PKE, and CR, but these values were derived from a very limited number of studies. Therefore, the objective of this study was to determine the STTD of P in CE, PKE, and CR fed to growing pigs.

\section{MATERIALS AND METHODS}

\section{Animal care}

The experimental procedure was approved by the Institutional Animal Care and Use Committee at Konkuk University.

\section{Animals, diet and feeding}

Eight barrows with a mean initial BW of $40.0 \mathrm{~kg}(\mathrm{SD}=$ 
4.5) were used to determine the ATTD and STTD of P in the $\mathrm{CE}$, PKE, and CR (Table 1). The pigs were individually placed in metabolism cages, and allotted to 4 dietary treatments and 3 periods in a replicated $4 \times 3$ incomplete Latin square design. Potential carryover effects were balanced using a spreadsheet-based program (Kim and Kim, 2010).

The amount of feed provided daily per pig was calculated as approximately 2.7 times the estimated energy requirement for maintenance (i.e., $106 \mathrm{kcal}$ of $\mathrm{ME}$ per $\mathrm{kg}$ of $\mathrm{BW}^{0.75}$; NRC, 1998). Daily feed allowance was divided into 2 equal meals and fed to the pigs at 0900 and 1700. Water was available at all times.

Three experimental diets contained $40 \%$ of CE, PKE or $\mathrm{CR}$ as the sole source of $\mathrm{P}$ (Tables 2 and 3). A P-free diet mainly based on corn starch, sucrose, and gelatin was also prepared to estimate the BEL of P. Vitamins and minerals were adequate to meet requirement estimates of $\mathrm{NRC}$ (1998).

\section{Sample collection}

An experimental period consisted of 3-d adaptation and 4-d collection periods. Total feces were collected according to the marker-to-marker procedure (Adeola, 2001). The total quantity of feces was immediately stored at $-20^{\circ} \mathrm{C}$ after collection. At the end of each period, the BW was measured to determine the amount of feed allowance.

\section{Chemical analysis}

Fecal samples were dried in a forced-air drying oven at $55^{\circ} \mathrm{C}$ and ground before analysis. To analyze DM in the ingredients, diets, and feces, all samples were dried in the forced-air drying oven at $135^{\circ} \mathrm{C}$ for $2 \mathrm{~h}$ (method 930.15; AOAC, 2005). The ingredients and diets were analyzed for GE (Model C2000, IKA, Germany), CP (method 990.03; AOAC, 2005), ether extract (method 920.39; AOAC, 2005), and crude fiber (method 978.10; AOAC, 2005) content. Samples of ingredients and diets were also analyzed for ash (method 942.05; AOAC, 2005), NDF (Goering and Van

Table 1. Energy and nutrient composition of copra expellers (CE), palm kernel expellers (PKE), and cassava root (CR), as-is basis

\begin{tabular}{lccc}
\hline Item & CE & PKE & CR \\
\hline DM (\%) & 89.9 & 90.8 & 88.3 \\
GE (kcal/kg) & 4,336 & 4,506 & 3,611 \\
CP $(\%)$ & 20.1 & 16.8 & 3.42 \\
Ether extract (\%) & 7.36 & 6.79 & 0.29 \\
Crude fiber (\%) & 9.48 & 13.1 & 5.41 \\
Ash (\%) & 6.81 & 3.95 & 6.39 \\
Calcium (\%) & 0.11 & 0.18 & 0.47 \\
Phosphorus (\%) & 0.53 & 0.63 & 0.11 \\
NDF (\%) & 54.7 & 67.2 & 16.5 \\
ADF (\%) & 30.8 & 38.7 & 9.66 \\
\hline
\end{tabular}

Table 2. Ingredient composition of experimental diets, as-fed basis

\begin{tabular}{lcccc}
\hline \multirow{2}{*}{ Ingredient (\%) } & \multicolumn{4}{c}{ Diet $^{1}$} \\
\cline { 2 - 5 } & CE & PKE & CR & P-free \\
\hline Corn starch & 29.00 & 26.70 & 18.60 & 45.19 \\
Copra expellers & 40.00 & - & - & - \\
Palm kernel expellers & - & 40.00 & - & - \\
Cassava root & - & - & 40.00 & - \\
Sucrose & 20.00 & 20.00 & 20.00 & 20.00 \\
Soybean oil & 1.70 & 2.00 & 4.50 & 4.70 \\
Gelatin & 8.00 & 10.00 & 16.00 & 17.00 \\
Cellulose & - & - & - & 10.00 \\
DL-methionine & - & - & - & 0.30 \\
L-threonine & - & - & - & 0.10 \\
L-tryptophan & - & - & - & 0.11 \\
L-histidine & - & - & - & 0.10 \\
L-isoleucine & - & - & - & 0.10 \\
Ground limestone & 0.40 & 0.40 & - & 1.00 \\
Potassium carbonate & - & - & - & 0.40 \\
Magnesium oxide & - & - & - & 0.10 \\
Salt & 0.40 & 0.40 & 0.40 & 0.40 \\
Vitamin-mineral & 0.50 & 0.50 & 0.50 & 0.50 \\
premix ${ }^{2}$ & & & &
\end{tabular}

${ }^{1} \mathrm{CE}=$ Copra expellers $40 \%$ diet; PKE $=$ Palm kernel expellers $40 \%$ diet; $\mathrm{CR}=$ Cassava root $40 \%$ diet; $\mathrm{P}$-free $=$ Phosphorus-free diet.

${ }^{2}$ Provided the following quantities per $\mathrm{kg}$ of complete diet: vitamin $\mathrm{A}$, 25,000 IU; vitamin $\mathrm{D}_{3}$, 4,000 IU; vitamin $\mathrm{E}, 50 \mathrm{IU}$; vitamin $\mathrm{K}, 5.0 \mathrm{mg}$; thiamin, $4.9 \mathrm{mg}$; riboflavin, $10.0 \mathrm{mg}$; pyridoxine, $4.9 \mathrm{mg}$; vitamin $\mathrm{B}_{12}$, $0.06 \mathrm{mg}$; pantothenic acid, $37.5 \mathrm{mg}$; folic acid, $1.10 \mathrm{mg}$; niacin, $62 \mathrm{mg}$; biotin, $0.06 \mathrm{mg}$; $\mathrm{Cu}, 25 \mathrm{mg}$ as copper sulfate; $\mathrm{Fe}, 268 \mathrm{mg}$ as iron sulfate; I, $5.0 \mathrm{mg}$ as potassium iodate; $\mathrm{Mn}, 125 \mathrm{mg}$ as manganese sulfate; Se, $0.38 \mathrm{mg}$ as sodium selenite; $\mathrm{Zn}, 313 \mathrm{mg}$ as zinc oxide; butylated hydroxytoluene, $50 \mathrm{mg}$.

Soest, 1970), and ADF (method 973.18; AOAC, 2005) content. The Ca concentrations in the ingredients, diets, and feces were analyzed using an atomic absorption spectrophotometer (method 978.02; AOAC, 2005; Perkin

Table 3. Analyzed chemical composition of experimental diets, as-fed basis

\begin{tabular}{lcccc}
\hline \multirow{2}{*}{ Item } & \multicolumn{4}{c}{ Diet $^{1}$} \\
\cline { 2 - 5 } & CE & PKE & CR & P-free \\
\hline DM (\%) & 92.2 & 92.1 & 91.0 & 92.7 \\
GE (kcal/kg) & 4,124 & 4,234 & 4,175 & 4,206 \\
CP (\%) & 16.4 & 16.8 & 18.8 & 18.9 \\
Ether extract (\%) & 4.72 & 4.65 & 4.79 & 4.75 \\
Crude fiber (\%) & 3.14 & 5.01 & 2.08 & 4.42 \\
Ash (\%) & 3.70 & 2.66 & 3.10 & 2.38 \\
Calcium (\%) & 0.18 & 0.40 & 0.21 & 0.52 \\
Phosphorus (\%) & 0.22 & 0.25 & 0.04 & 0.01 \\
NDF (\%) & 22.8 & 27.1 & 8.04 & 10.8 \\
ADF (\%) & 10.6 & 15.5 & 4.16 & 6.42 \\
\hline
\end{tabular}

${ }^{1} \mathrm{CE}=$ Copra expellers $40 \%$ diet; PKE = Palm kernel expellers $40 \%$ diet; $\mathrm{CR}=$ Cassava root $40 \%$ diet; $\mathrm{P}$-free $=$ Phosphorus-free diet . 
Elmer 3300, Perkin Elmer, USA). The P concentrations in the ingredients, diets, and feces were analyzed using a spectrophotometer (method 946.06; AOAC, 2005; Optizen 2120UV, Mecasys, Republic of Korea).

\section{Calculations}

Phosphorus digestibility was calculated based on the $\mathrm{P}$ intake and the amount of excreted P (Kim et al., 2012). Because the CE, PKE, and CR were the sole source of $\mathrm{P}$ in each experimental diet, values for the ATTD of $\mathrm{P}$ in each experimental diet represent values for the ATTD of $P$ in the $\mathrm{CE}, \mathrm{PKE}$, and CR. The ATTD of P was calculated according to the following equation:

$$
\text { ATTD of } \mathrm{P}(\%)=[(\mathrm{Pi}-\mathrm{Po}) / \mathrm{Pi}] \times 100
$$

where $\mathrm{Pi}$ is the total $\mathrm{P}$ intake $(\mathrm{g})$ during collection period (from $\mathrm{d} 4$ to 7 ) and Po is the total fecal P output (g) during collection period.

The BEL of $\mathrm{P}$ was calculated based on the DMI and excreted $\mathrm{P}$ from the pigs fed the P-free diet. The BEL of $\mathrm{P}$ was calculated according to the following equation:

BEL of $\mathrm{P}(\mathrm{mg} / \mathrm{kg}$ of $\mathrm{DMI})=[(\mathrm{Po} / \mathrm{Fi}) \times 1,000 \times 1,000]$

where $\mathrm{Fi}$ is the total feed DMI $(\mathrm{g})$ during the collection period. The BEL of $\mathrm{P}(\mathrm{g})$ in pigs fed experimental diets except the P-free diet was calculated by multiplying the calculated BEL of P ( $\mathrm{g} / \mathrm{kg}$ of DMI) by the total feed DMI of each pig during the collection period (Kim et al., 2012).

The STTD of $\mathrm{P}$ was calculated according to the following equation:

$$
\text { STTD of } \mathrm{P}(\%)=\{[\mathrm{Pi}-(\mathrm{Po}-\mathrm{BEL} \text { of } \mathrm{P})] / \mathrm{Pi}\} \times 100
$$

\section{Statistical analysis}

Data were analyzed using the MIXED procedure of SAS (SAS Inst. Inc., Cary, NC, USA). Variation within treatment and outlier were tested using the UNIVARIATE procedure. The model included dietary treatment as the fixed variable and replication, animal within replication, and period within replication as random variables. Least squares means of each treatment were calculated and the differences between means were tested using the PDIFF option with Tukey's adjustment. In this process, the output values were converted to letter groupings using a macro program (Saxton, 1998). The experimental unit was a pig, and the statistical significance was set at $p$-value $<0.05$. The prediction equation for the BEL of $\mathrm{P}(\mathrm{mg} / \mathrm{kg}$ of DMI) was developed by using PROC REG, and the equation used the initial BW $(\mathrm{kg})$ as an independent variable.

\section{RESULTS}

\section{Chemical composition}

The contents of $\mathrm{CP}$, ether extract, crude fiber, NDF, and $\mathrm{ADF}$ in $\mathrm{CE}$ and PKE were greater than those in CR (Table 1). The contents of $\mathrm{Ca}$ in $\mathrm{CE}$ and PKE were less than those in $\mathrm{CR}$, but the contents of $\mathrm{P}$ in $\mathrm{CE}$ and $\mathrm{PKE}$ were greater than those in CR.

\section{Phosphorus and calcium digestibility}

The ATTD of p-values in CE and PKE were greater than that in CR (46.0 and 39.7 vs $-14.0 \%$; $p<0.05$; Table 4). The BEL of $\mathrm{P}$ was calculated at $252 \pm 15 \mathrm{mg} / \mathrm{kg}$ of DMI in pigs fed the P-free diet. Values for the STTD of P in CE, PKE, and CR did not differ greatly $(56.5,49.0$, and $43.2 \%$, respectively; $\mathrm{p}=0.222$ ).

Calcium digestibility was calculated based on the $\mathrm{Ca}$ intake and the amount of excreted $\mathrm{Ca}$ (Table 4). The $\mathrm{Ca}$ intake of pigs fed the PKE diet was greater than that in the CE- or CR-fed group $(\mathrm{p}<0.05)$. The ATTD of $\mathrm{Ca}$ in PKE was greater than that in $\mathrm{CE}(58.6$ vs $28.3 \%$; $\mathrm{p}<0.05)$.

\section{DISCUSSION}

\section{Chemical composition}

The $\mathrm{P}$ contents in the $\mathrm{CE}$ and PKE used in this experiment were similar to the values reported previously (Sauvant et al., 2004; Almaguer et al., 2011; NRC, 2012). The $\mathrm{P}$ content in the CR used in this experiment was similar to the value ( 0.11 vs $0.12 \%$ ) reported by the NRC (2012).

\section{Phosphorus and calcium digestibility}

The reason that the difference in digestibility was observed in ATTD but not in STTD is most likely due to the different $\mathrm{P}$ content in the experimental diets. The total $\mathrm{P}$ intake in pigs fed the $\mathrm{CR}$ diet was less than that in pigs fed the CE or PKE diet. When the P intake is small, the proportion of the BEL of $\mathrm{P}$ in the total quantity of excreted P increases (Kim et al., 2012). For this reason, the ATTD of $P$ in the $C R$ used in this experiment was a negative value.

The STTD of P in the CE used in this experiment was less than the value reported by Almaguer et al. (2011) and the NRC (2012). The value for the STTD of P in PKE in the present work was very similar to the values reported in the literature (Almaguer et al., 2011; NRC, 2012). The STTD of $\mathrm{P}$ in the $\mathrm{CR}$ in the present experiment was greater (43.2 vs $24.0 \%$ ) than the value reported by the NRC (2012). However, values for the STTD of P in the CE, PKE, and CR reported by the NRC (2012) were based on only 1, 2, and 1 study, respectively. The $\mathrm{P}$ digestibility values in the $\mathrm{CE}$, PKE, and CR were very limited; therefore, more studies are required to obtain $P$ digestibility values of the $\mathrm{CE}, \mathrm{PKE}$, and CR that are more accurate. 
Table 4. Digestibility of phosphorus $(\mathrm{P})$ and calcium $(\mathrm{Ca})$ in experimental diets fed to growing pigs ${ }^{1}$

\begin{tabular}{|c|c|c|c|c|c|}
\hline & \multicolumn{3}{|c|}{ Diet $^{2}$} & \multirow{2}{*}{ SEM } & \multirow{2}{*}{ p-value } \\
\hline & $\mathrm{CE}$ & PKE & $\mathrm{CR}$ & & \\
\hline \multicolumn{6}{|l|}{ Feed intake $(\mathrm{g} / \mathrm{d})$} \\
\hline Total feed intake & 1,136 & 1,250 & 1,331 & 111 & $<0.001$ \\
\hline Ca intake & $2.06^{\mathrm{b}}$ & $5.03^{\mathrm{a}}$ & $2.94^{\mathrm{b}}$ & 0.34 & $<0.001$ \\
\hline P intake & 2.48 & 3.13 & 0.60 & 0.29 & 0.089 \\
\hline \multicolumn{6}{|l|}{ Fecal output } \\
\hline Total feces (g/d) & $110^{\mathrm{b}}$ & $194^{\mathrm{a}}$ & $75.6^{\mathrm{c}}$ & 68.9 & $<0.001$ \\
\hline $\mathrm{Ca}$ in feces $(\%)$ & 1.29 & 1.16 & 1.57 & 0.12 & 0.246 \\
\hline $\mathrm{P}$ in feces $(\%)$ & $1.16^{\mathrm{a}}$ & $1.10^{\mathrm{a}}$ & $0.66^{\mathrm{b}}$ & 0.09 & 0.024 \\
\hline Ca output (g/d) & 1.52 & 2.13 & 1.45 & 0.30 & 0.233 \\
\hline P output $(\mathrm{g} / \mathrm{d})$ & $1.37^{\mathrm{ab}}$ & $1.96^{\mathrm{a}}$ & $0.64^{\mathrm{b}}$ & 0.29 & 0.012 \\
\hline \multicolumn{6}{|l|}{ Digestibility (\%) } \\
\hline $\mathrm{ATTD}^{3}$ of $\mathrm{Ca}$ & $28.3^{\mathrm{b}}$ & $58.6^{\mathrm{a}}$ & $48.4^{\mathrm{ab}}$ & 5.09 & 0.004 \\
\hline ATTD of P & $46.0^{\mathrm{a}}$ & $39.7^{\mathrm{a}}$ & $-14.0^{\mathrm{b}}$ & 7.61 & $<0.001$ \\
\hline $\mathrm{STTD}^{3,4}$ of P & 56.5 & 49.0 & 43.2 & 7.61 & 0.222 \\
\hline
\end{tabular}

${ }^{\mathrm{a}, \mathrm{b}}$ Least squares of means within a row without a common superscript differ $(\mathrm{p}<0.05)$.

${ }^{1}$ Each least squares mean for CE, PKE, CR, and P-free treatments represents 5, 4, 3, and 4 observations, respectively.

${ }^{2} \mathrm{CE}=$ Copra expellers $40 \%$ diet; PKE $=$ Palm kernel expellers $40 \%$ diet; $\mathrm{CR}=$ Cassava root $40 \%$ diet; P-free $=$ Phosphorus-free diet.

${ }^{3}$ ATTD = Apparent total tract digestibility; STTD = Standardized total tract digestibility.

${ }^{4}$ Values for the STTD were calculated by correcting the ATTD values for the basal endogenous loss of P. The basal endogenous loss of P was estimated in pigs fed the P-free diet at $252 \pm 15 \mathrm{mg} / \mathrm{kg}$ of DMI.

The BEL of $\mathrm{P}$ estimated in this study $(252 \mathrm{mg} / \mathrm{kg}$ of DMI; Table 4) was not far off, but was slightly greater than previously reported values ( 153 to $211 \mathrm{mg} / \mathrm{kg}$ of DMI). The relatively high BEL of $\mathrm{P}$ in the present study may be associated with the rather heavy BW $(40 \mathrm{~kg})$ of the pigs used in this experiment compared with the pigs in other studies $(11.0$ to $33.2 \mathrm{~kg})$. The values for the BEL of $\mathrm{P}$ $(\mathrm{mg} / \mathrm{kg}$ of DMI) was positively correlated with the initial $\mathrm{BW}$ of pigs in the literature $\left(\mathrm{r}^{2}=0.669, \mathrm{p}=0.013\right.$; Figure 1).

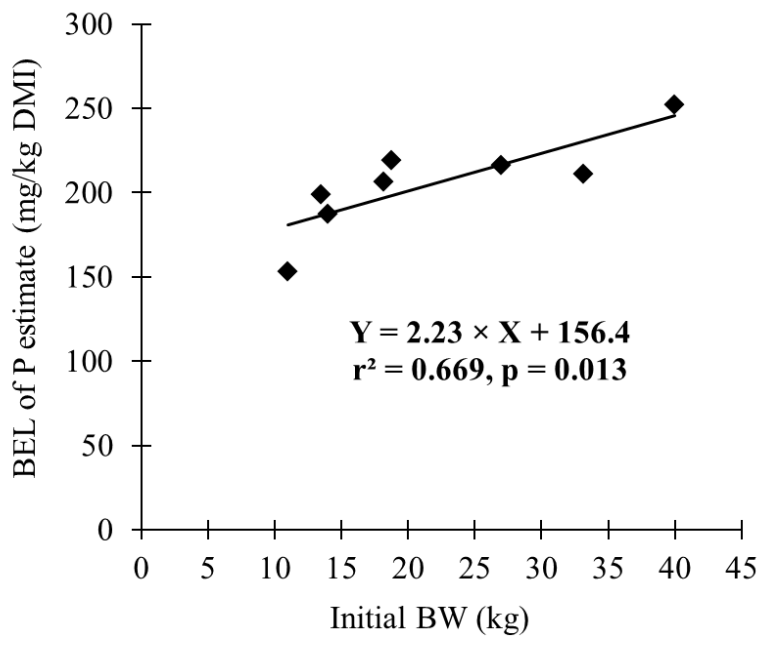

Figure 1. Relationship between basal endogenous loss (BEL) of phosphorus $(\mathrm{P})$ and initial BW of pig $(\mathrm{n}=8)$. Data are from Widmer et al. (2007), Almeida and Stein (2010, 2011, 2012), Almaguer et al. (2011), Kim et al. (2012), Rojas and Stein (2012), and the present study.
Furthermore, the concentration of the fiber source in the Pfree diet was also greater in this experiment $(10 \%$, as-fed basis; Comprecel, Mingtai Chemical Co., Ltd., Taiwan) than that in previous studies (4\%, as-fed basis; Solka-Floc, Fiber Sales and Development Corp., USA). It has been hypothesized that high fiber content in feed ingredients may increase the total endogenous losses of $\mathrm{P}$ (Petersen and Stein, 2006) because dietary fiber increases the turnover rate of intestinal cells (Jin et al., 1994). In the present work, thus, we included $10 \%$ of cellulose in the P-free diet that contained a similar ADF concentration to the CE, PKE, and $\mathrm{CR}$ diets.

The less ATTD of Ca in the CE diet as compared with that in the PKE diet may be attributed to the less digestibility of $\mathrm{Ca}$ in $\mathrm{CE}$, the less Ca intake in the CE group, or both. The ATTD of Ca has been reported to be positively correlated with $\mathrm{Ca}$ intake in pigs (González-Vega et al., 2013).

\section{CONCLUSION}

In conclusion, values for the ATTD of P in CE and PKE were greater than that in CR, but the STTD of P among CE, PKE, and CR did not differ greatly. The STTD is more accurate that the ATTD when expressing the digestibility of $\mathrm{P}$, for low-P content ingredients.

\section{ACKNOWLEDGEMENTS}

This study was supported by Farm Story Dodram B\&F 
(Seoul, Republic of Korea) and the National Institute of Animal Science (Suwon, Republic of Korea; PJ907038).

\section{REFERENCES}

Adeola, O. 2001. Digestion and balance techniques in pigs. In: Swine Nutrition (Ed. A. J. Lewis and L. L. Southern) CRC Press, Washington, DC. pp. 903-916.

Almaguer, B. L., R. C. Sulabo, and H. H. Stein. 2011. Effects of phytase on standardized total tract digestibility of $\mathrm{P}$ in copra expellers, palm kernel expellers, and palm kernel meal fed to growing pigs. J. Anim. Sci. 89 (E-Suppl. 1):187 (Abstr.).

Almeida, F. N. and H. H. Stein. 2010. Performance and phosphorus balance of pigs fed diets formulated on the basis of values for standardized total tract digestibility of phosphorus. J. Anim. Sci. 88:2968-2977.

Almeida, F. N. and H. H. Stein. 2011. Standardized total tract digestibility of phosphorus in blood products fed to weanling pigs. Rev. Colomb. Cienc. Pecu. 24:617-622.

Almeida, F. N. and H. H. Stein. 2012. Effects of graded levels of microbial phytase on the standardized total tract digestibility of phosphorus in corn and corn coproducts fed to pigs. J. Anim. Sci. 90:1262-1269.

AOAC. 2005. Official methods of analysis, 18th edn. Association of Official Analytical Chemists, Arlington, Virginia.

Crenshaw, T. D. 2001. Calcium, phosphorus, vitamin D, and vitamin K. In: Swine Nutrition (Ed. A. J. Lewis and L. L. Southern) CRC Press, Washington, DC. pp. 187-212.

Goering, H. K. and P. J. Van Soest. 1970. Forage fiber analysis (apparatus, reagents, procedures and some applications). Agriculture Handbook No. 379. ARS, USDA, Washington, DC.

González-Vega, J. C., C. L. Walk, Y. Liu, and H. H. Stein. 2013. Determination of endogenous intestinal losses of calcium and true total tract digestibility of calcium in canola meal fed to growing pigs. J. Anim. Sci. 91:4807-4816.

Jin, L., L. P. Reynolds, D. A. Redmer, J. S. Caton, and J. D. Crenshaw. 1994. Effects of dietary fiber on intestinal growth, cell proliferation, and morphology in growing pigs. J. Anim. Sci. 72:2270-2278.
Kim, B. G., J. H. Lee, H. J. Jung, Y. K. Han, K. M. Park, and I. K. Han. 2001. Effect of partial replacement of soybean meal with palm kernel meal and copra meal on growth performance, nutrient digestibility and carcass characteristics of finishing pigs. Asian-Aust. J. Anim. Sci. 14:821-830.

Kim, B. G. and T. M. Kim. 2010. A program for making completely balanced Latin square designs employing a systemic method. Rev. Colomb. Cienc. Pecu. 23:277-282.

Kim, B. G., J. W. Lee, and H. H. Stein. 2012. Energy concentration and phosphorus digestibility in whey powder, whey permeate, and low-ash whey permeate fed to weanling pigs. J. Anim. Sci. 90:289-295.

National Research Council (NRC). 1998. Nutrient requirements of swine. 10th Ed. National Academy Press, Washington, DC.

National Research Council (NRC). 2012. Nutrient requirements of swine. 11th Ed. National Academy Press, Washington, DC.

Petersen, G. I. and H. H. Stein. 2006. Novel procedure for estimating endogenous losses and measurement of apparent and true digestibility of phosphorus by growing pigs. J. Anim. Sci. 84:2126-2132.

Rojas, O. J. and H. H. Stein. 2012. Digestibility of phosphorus by growing pigs of fermented and conventional soybean meal without and with microbial phytase. J. Anim. Sci. 90:15061512.

Sauvant, D., J. -M. Perez, and G. Tran. 2004. Tables of composition and nutritional value of feed materials. Academic Publishers, Wageningen, The Netherlands.

Saxton, A. M. 1998. A macro for converting mean separation output to letter groupings in Proc Mixed. Proc. 23rd SAS Users Group International. SAS Institute, Cary, NC. pp. 12431246.

Son, A. R., S. Y. Ji, and B. G. Kim. 2012. Digestible and metabolizable energy concentrations in copra meal, palm kernel meal, and cassava root fed to growing pigs. J. Anim. Sci. 90:140-142.

Widmer, M. R., L. M. McGinnis, and H. H. Stein. 2007. Energy, phosphorus, and amino acid digestibility of high-protein distillers dried grains and corn germ fed to growing pigs. J. Anim. Sci. 85:2994-3003. 